\title{
Monetary and fiscal policy mix connectivity towards the business cycle in Indonesia
}

\author{
Regina Niken Wilantari ${ }^{1 *}$; Imro'atul Husna Afriani ${ }^{2}$ \\ ${ }^{1)}$ Economics Department, Faculty of Economics and Business, Universitas Jember, \\ Indonesia \\ ${ }^{2)}$ English Education Study Program, Universitas 17 August 1945, Indonesia \\ *To whom correspondence should be addressed. Email: reginanikenw.feb@unej.ac.id

\begin{tabular}{|l|l|l|l|l}
\hline DOI: & Received: & Revised: & Accepted: & Published: \\
$10.22437 /$ ppd.v9i2.11489 & 25.12 .2020 & 19.04 .2021 & 18.06 .2021 & 30.06 .2021 \\
\hline
\end{tabular}

\begin{abstract}
This research is based on the magnitude of the influence of monetary and fiscal aspects, namely the money supply, exchange rates, government spending, and taxes on the business cycle in Indonesia. This study aims to examine the effect of the connection between the monetary and fiscal policy mix on the business cycle in Indonesia. For analysis purposes, secondary data was used in the form of time-series data from 1970 2017. The method used is the Vector Error Correction Model (VECM) to see long-term and short-term relationships. In the estimation results, it is found that in the long-term period, the monetary variables (money supply and exchange rates) and fiscal variables (government expenditures and taxes) have a significant positive effect on the business cycle in Indonesia.In contrast, the monetary variables that have a significant effect in the short-term period are only the amount variable money supply. There are no fiscal variables that have a significant effect on the business cycle in Indonesia. The interaction of monetary and fiscal policies is still effectively implemented in Indonesia.
\end{abstract}

Keywords: Business Cycle, Monetary, Money Supply, Vector Error Correction Model

JEL Classification: C01, E44, E51

\section{INTRODUCTION}

A country is experiencing steady growth or increasing every year, and this situation indirectly describes the development of various economic sectors that occur. This is inseparable from an important indicator that is the success of the development process in the long term. Economic growth is an indicator of a country that can facilitate more goods and services to the community (Villanthenkodath \& Mahalik, 2021; Harnphattananusorn \& Puttitanun, 2021). This capability is certainly supported by massive technological developments as well as the necessary institutional and ideological adjustments. In addition, it is usually supported by high resources, both natural and human resources, as well as a country's budget. Potentially, economic growth tends to increase workers' productivity, and the business unit scale can increase. However, this does not always go as planned by the government concerned because, in essence, economic growth fluctuates from time to time (Bogoviz, 2020; Mao et al., 
2020).

In real terms, the fluctuation of economic growth can be seen from GDP (Gross Domestic Product) based on periodic consumer prices. This means that growth can be said to be positive if the economy increases and vice versa. Economic fluctuations by looking at GDP can be prevented by using two policies taken by policymakers, namely monetary and fiscal policies (Herzog, 2014; Boakye et al., 2020). Monetary policy is an effort made by the government through the monetary authority in controlling the economy in the macro sphere so that the economy remains stable through its instruments such as interest rates, the amount of money in circulation, and others (Xu, 2020; McDonald \& Stokes, 2015). This economic condition can be seen from the increased stability of output and stable price stability. Meanwhile, fiscal policy is a policy from the government that is used to direct a stable or even increasing economy with indicators such as taxes and government spending (Gitman et al., 2015; Viphindrartin, 2021).

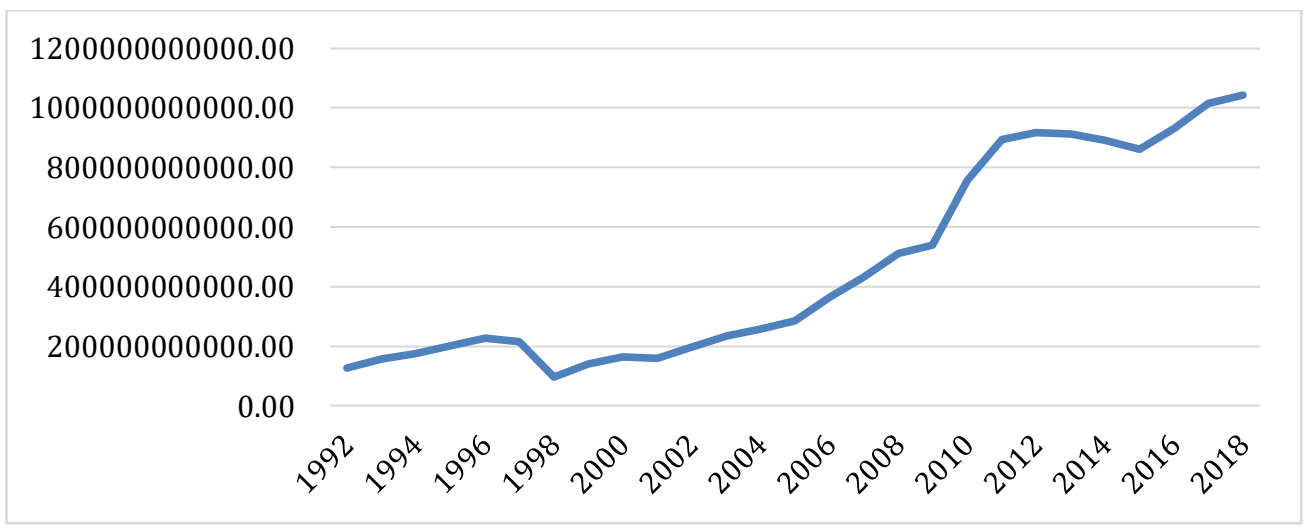

Source: World Bank, compiled

Figure 1. Indonesia's GDP movement in the current US \$

Indonesia's economic growth is shown in Figure 1. It seems to fluctuate. However, Indonesia's GDP tended to grow from 1992 to 2018. Various factors influenced the fluctuation in the value of Indonesia's GDP. Role of the government and Bank Indonesia as the central bank in Indonesia plays a role in managing the economy through policies, namely monetary and fiscal policies because these two policies impact the Indonesian economy as reflected in GDP.

Monetary effectiveness is influenced by the relationship between the money supply and economic variables such as inflation and output (Hidayanti \& Prabowo, 2021; Widarni \& Bawono, 2021). This statement is proven by a literature study that records the relationship between the money supply, output, and inflation. This study shows the relationship between the money supply and perfect inflation in the long run, whereas money growth or inflation and real output may be close to zero. This monetary policy will affect inflation and will not affect the real sector. Some academics and practitioners believe that in the short term, the expansionary monetary policy prevents economic activity when there is a recession. In contrast, contractionary policies can push up the inflation rate when the economy is booming (Dunning, 2014; Song et al., 2020).

When a country's economy experiences an economic slowdown and a high unemployment rate, a policy is needed that can encourage stable or even increasing economic growth and minimized unemployment (Omofa,2017; Garang et al.,2018). 
Meanwhile, when the economic condition is felt to be overheating followed by a high inflation rate, the two policies are expected to be a solution for the government to avoid its negative effects. Economic conditions that are difficult to predict have made the stakeholders of each of these policies have to observe and analyze every variable that can affect shocks that will impact conditions of economic growth. This step was taken because it is very important to know the policy response that each of these policymakers will take. The current government needs macroeconomic policies to coordinate a policy originating from the monetary and fiscal authorities to create an effective policy (Melicher \& Norton, 2013; Drean, 2021).

Discussions related to coordination between monetary and fiscal policies have long been a topic of discussion for academics, economists in both developed and developing countries. The results are as mixed as some economists say if the mix of the two policies positively impacts economic growth. Meanwhile, some assume that each of these authorities does not pay attention to the policies' behavior. Implementing the policies does not run optimally, thus causing many differences to the policy mix in stimulating ongoing economic stability. The view of the classics says that the effectiveness of monetary and fiscal policies is not the most effective method of stimulating the economy.

In contrast, the view Keynes is different from that of the classics. Keynes explained that monetary and fiscal stimuli could prevent a decline in real output. The difference in views is seen from an economic perspective (Davar, 2016; Marglin,2018). Meanwhile, the inflation problem, which is the duty of Bank Indonesia as the monetary authority, can trigger a high inflation rate, or even hyperinflation will occur due to the influence of deficit financing that is too high, which triggers an economic recession. Realizing this, the government, through the fiscal authority, issued policies by controlling government spending by increasing tax revenue.

Regarding the management of the economic cycle, the classics believe that monetary policy is more effective in influencing inflation control. This is based on the assumption that when the economy experiences full employment, the money function is only used for transaction motives. The demand for money will change when there is a change in income, but because the money function is only used for transaction motives, the demand for money does not affect changes in the price level. The vertical LM curve illustrates this so that the elasticity of money demand against the interest rate is zero. When the economy is at the point of full employment where there is a balance that has reached the maximum point, the policy is taken by the ministerial authority through the money supply instrument only affects the inflation rate (Handa,2008; Damayanti \& Rusminingsih, 2021).

The inflation problem can indeed be controlled by monetary policy, but the classics reject this assumption if this monetary policy affects economic activity as a whole. This is related to the market mechanism, which continues to experience balance in the economy. Thus, the addition of the money supply will not affect the real sector but will impact the magnitude of the inflation rate (Hutton, 2012; Aßhoff et al., 2021).

The classical theory experienced rapid development to become a modern quantity theory or known as the monetarist flow. According to this flow, when the economy has not reached full employment, policies that use money in circulation instruments will affect real output prices. Monetary flow assumes that relying solely on monetary policy is not enough to influence the economy because this impact is direct. From a fiscal perspective, classical and monetary schools believe that the market mechanism will achieve economic balance without any intervention from the government. Fiscal policy 
will only give rise to the term "crowding out," which is that high government spending will cause interest rates to rise and thus discourage private investment. This hampered investment will cause aggregate demand not to increase and output to stagnate or remain. Then, the expenditure side, which is not followed by a large money supply (from the fiscal side), will not increase aggregate demand. This concept is inseparable from the relatively stable velocity of money, so the addition of the money supply will increase aggregate demand (Stimson et al., 2013; Chen et al., 2021).

The economic depression of 1963 has resulted in new thinking about the necessity of government intervention in the economy. Keynes emphasized that in the economy, there must be government intervention. The government functions not only as a tax collector and guardian of security, but the government also has regulatory rights and an intervention function. In Keynes's view, if an expansionary fiscal policy, the results will remain expansionary. Keynes also added that if there was an additional motive, namely holding money for speculative activities. This speculation motive is influenced by the interest rate, which will impact the amount of investment. This interest rate and investment have a positive relationship (Clarke et al., 2019).

Economic fluctuations always occur to accompany the economy from time to time (Bawono et al., 2019). When the economy is at the lowest point (trough), it can move towards the recovery stage until it reaches its peak (peaks). This recovery process can be fast, and it can be very slow. Fluctuations in the economy are influenced by movements in output, prices, interest rates, and job opportunities which become macroeconomic variables and shape the business cycle. These jumps triggered repeated recessions and expansions.

Real business cycle theory also assumes that technology shocks will affect fluctuations in output. Technology becomes a variable that determines the amount of output produced. When technology develops, the output level will also develop, the company's output will also increase. Conversely, a recession is a condition in which technology has decreased. On the flexibility of wages and prices, this theory explains a clear market that uses the assumption that prices and wages are adjusted quickly according to the state of the economy. In other words, the market will adjust to the equilibrium point quickly (Hartley et al., 2013).

Keynes's assumptions respond to inflation based on macroeconomic theory and highlight other aspects of inflation. This theory explains that if inflation occurs due to society having a desire to live outside the maximum limits of its economy, the aggregate demand generated by society for goods and services exceeds the aggregate supply of goods and services available. This condition will cause an inflationary gap. The limited supply of goods and services (aggregate supply) occurs in the short run because production capacity cannot be developed to compensate for aggregate demand, which has experienced a drastic increase. Therefore, just like monetarists' view, Keynesianism is widely used to describe the phenomenon of the emergence of inflation in the short run (Vroey, 2016).

The heterogeneous purchasing power of society triggers the reallocation of goods and services available from people who have lower purchasing power desires to people who have higher purchasing power desires. This situation will continue to be repeated in the community (Gerdesmeier, 2011).

New Keynesian assumes that irrational behavior influencing information is not fully acceptable. This will affect the behavior of companies and households in the economy. Information is sticky (sticky information), causing companies to constantly receive information because there is an interval between the latest information. The 
New Keynesian school considers information assumptions to have a preference on a set price. In contrast to the Neoclassical school, which assumes that individuals can move dynamically by optimizing choice preferences with available information. Thus everyone is at the optimal level of adjustment. The difference between Neoclassical and New Keynesian assumptions will influence the decisions that will be taken in the business world (Grauwe \& Ji, 2019).

The assumptions made by the two streams affect understanding the main sources of the causes of the business cycle in the business world in accordance with the policies that policymakers will take in the economy to comply with their countries. So that the business cycle can be measured from macroeconomic variables. This can be seen in the New Keynesian assumption that if monetary quantities are included in the business cycle model, that affects the output. At present, it is also seen that every country has a central bank that aims to help boost the economy from monetary instruments. Monetary variables used in analyzing the relationship between monetary and fiscal policy mix to the business cycle are the money supply (M2), exchange rates, and inflation.

Meanwhile, the fiscal variables used in this study are taxes and government spending. This study is measured in the business cycle of GDP. Gross Domestic Product (GDP) measures the total income and expenditure of the economy. GDP is a natural place to start an analysis of the business cycle (Jacobs, 2012).

Monetary policy in a country aims to maintain economic stability through a stable currency value reflected in other countries' price levels and currencies. The monetary authority determines monetary policy by considering real economic conditions. A balanced economy can be achieved between the government's monetary policy and fiscal policy to achieve the same goal: economic growth. This requires alignment between policies carried out by the government and economic conditions. The monetary authority's direction of independent monetary policies must also be in line with government policies, both fiscal and trade policies. When these policies are without the same direction from one policy to another, it will cause an imbalance in the economy. The government's policy to increase inflows by opening trade flows must also be in line with the policies adopted by the central bank, namely through the financial market by regulating low-interest rates for securities, both debt securities and capital stock. If policies carried out in the opposite direction become incompatible and the economy becomes disrupted. Thus, the interconnection of the monetary and fiscal policy mix is the subject of discussion of the business cycle in Indonesia to describe the economy as progressing (Caprio \& Bacchetta, 2012; Sequeira, 2021).

\section{METHODS}

The type of data used in this study is secondary data in the form of a time series with the research year between the period 1970-2017 in Indonesia. The objective in selecting the research year period is based on stable economic conditions in Indonesia after the ASEAN crisis in the 1997/1998 period. In addition, adjusting to the business cycle period estimated by economists to be between one and 10 or 12 years. Meanwhile, data were obtained from various statistical data published by various sources such as Bank Indonesia, the Central Bureau of Statistics (BPS), and the International Monetary Fund (IMF). This study used the Vector Error Correction Model (VECM) method.

This study includes the relationship between the variable money supply, exchange rate, taxes, and government spending to determine the policy mix interaction between monetary policy and fiscal policy on the business cycle. This study is measured in the business cycle of GDP. The Gross Domestic Product (GDP) measures the total income 
and expenditure of the economy. This is because GDP is a natural place to start an analysis of the business cycle. The research focuses on the business world and the behavior of economic actors towards the economy. So that the economic model is obtained as follows:

GDP = F (M2, EXR, TAX, GE, INF)

So if it is derived in the form of an econometric model, it is as follows:

$\mathrm{GDP}_{\mathrm{t}}=\alpha_{0}+\beta_{1} \mathrm{M} 2_{\mathrm{t}-1}+\beta_{2} \mathrm{EXR}_{\mathrm{t}-1}+\beta_{3} \mathrm{TAX}_{\mathrm{t}-1}+\beta_{4} \mathrm{GE}_{\mathrm{t}-1}+\beta_{5} \mathrm{INF}_{\mathrm{t}-1}+\mu_{\mathrm{t}}$

Where :

$\mathrm{GDP}_{\mathrm{t}}=$ Gross Domestic Product (GDP) is a proxy product of the business cycle

$\mathrm{M} 2$ = money supply (M2)

EXR = Exchange Rate (domestic exchange rate $/ \$$ )

$\mathrm{TAX}=\mathrm{Tax}$

$\mathrm{GE}=$ Government Expenditure or Government Expenditure

$\mathrm{INF}=$ Inflation .

Meanwhile, it is necessary to approach the Vector Error Correction Model (VECM) method to estimate in the long term. The formulation of the VECM model is as follows:

$$
\Delta \mathrm{X}_{\mathrm{t}}=\alpha_{0}+\sum_{i=1}^{k-1} \quad \Gamma \Delta \mathrm{X}_{\mathrm{t}-1}+\alpha \beta^{\prime} \mathrm{X}_{\mathrm{t}-\mathrm{k}}+\mathrm{e}_{\mathrm{t}}
$$

Keterangan:

$$
\begin{array}{ll}
\Gamma \Delta \mathrm{X}_{\mathrm{t}-1} & =\text { Variable short-term relationship } \\
\alpha_{0} & =\text { Coefficient } \\
\alpha & =\text { Parameter } \\
\beta &
\end{array}
$$

$$
\begin{aligned}
& \Delta \mathrm{GDP}_{\mathrm{t}}=\alpha_{10}+\mathrm{GDP}_{\mathrm{t}-1}+\alpha_{11} \mathrm{M}_{2 \mathrm{t}-1}+\alpha_{12} \mathrm{EXR}_{\mathrm{t}-1}+\alpha_{13} \mathrm{TAX}_{\mathrm{t}-1}+\alpha_{14} \Delta \mathrm{GE}_{\mathrm{t}-1}+\alpha_{15} \Delta \mathrm{INF}_{\mathrm{t}-1} \\
& { }_{+} \alpha_{16} \Delta \mathrm{GDP}_{\mathrm{t}-\mathrm{n}}+\Delta \alpha_{17} \mathrm{GDPt}_{-1}+\Delta \alpha_{18} \mathrm{M}_{2 \mathrm{t}_{-\mathrm{n}}}+\Delta \alpha_{19} \mathrm{M}_{2 \mathrm{t}_{-\mathrm{n}}}+\Delta \alpha_{20} \mathrm{EXR}_{\mathrm{t}-1}+\alpha_{21} \mathrm{EXR}_{\mathrm{t}-\mathrm{n}}+ \\
& \Delta \alpha_{22} \mathrm{TAX}_{\mathrm{t}-1}+\Delta \alpha_{23} \mathrm{TAX}_{\mathrm{t}-1}+\Delta \alpha_{24} \mathrm{GEX}_{\mathrm{t}-1}+\Delta \alpha_{25} \mathrm{GEX}_{\mathrm{t}-1}+\Delta \alpha_{26} \mathrm{INF}_{\mathrm{t}-1}+\alpha_{27} \mathrm{INF}_{\mathrm{t}-\mathrm{n}} \\
& \Delta \mathrm{M} 2_{\mathrm{t}}=\alpha_{20}+\mathrm{GDP}_{\mathrm{t}-1}+\alpha_{21} \mathrm{M}_{2} \mathrm{t}_{-1}+\alpha_{22} \mathrm{EXR}_{\mathrm{t}-1}+\alpha_{23} \mathrm{TAX}_{\mathrm{t}-1}+\alpha_{24} \Delta \mathrm{GE}_{\mathrm{t}-1}+\alpha_{25} \Delta \mathrm{INF}_{\mathrm{t}-1} \\
& { }_{+} \alpha_{26} \Delta \mathrm{GDP}_{\mathrm{t}-\mathrm{n}}+\Delta \alpha_{27} \mathrm{GDPt}_{-1}+\Delta \alpha_{28} \mathrm{M}_{2 \mathrm{t}_{-\mathrm{n}}}+\Delta \alpha_{29} \mathrm{M} 2 \mathrm{t}_{-\mathrm{n}}+\Delta \alpha_{30} \mathrm{EXR}_{\mathrm{t}-1}+\alpha_{31} \mathrm{EXR}_{\mathrm{t}-\mathrm{n}}+
\end{aligned}
$$

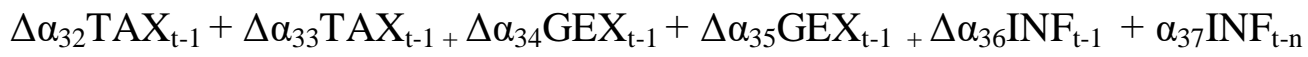

$\Delta \mathrm{EXR}_{\mathrm{t}}=\alpha_{30}+\mathrm{GDP}_{\mathrm{t}-1}+\alpha_{31} \mathrm{M}_{2 \mathrm{t}}+\alpha_{32} \mathrm{EXR}_{\mathrm{t}-1}+\alpha_{33} \mathrm{TAX}_{\mathrm{t}-1}+\alpha_{34} \Delta \mathrm{GE}_{\mathrm{t}-1}+\alpha_{35} \Delta \mathrm{INF}_{\mathrm{t}-1}$

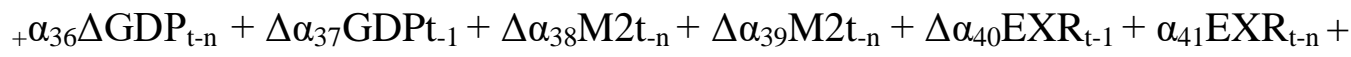

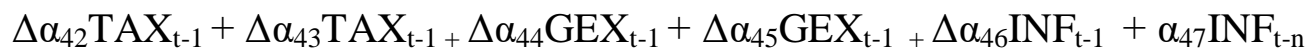

$\Delta \mathrm{TAX}_{\mathrm{t}}=\alpha_{40}+\mathrm{GDP}_{\mathrm{t}-1}+\alpha_{41} \mathrm{M}_{2 \mathrm{t}}+1+\alpha_{42} \mathrm{EXR}_{\mathrm{t}-1}+\alpha_{43} \mathrm{TAX}_{\mathrm{t}-1}+\alpha_{44} \Delta \mathrm{GE}_{\mathrm{t}-1}+\alpha_{45} \Delta \mathrm{INF}_{\mathrm{t}-1}$

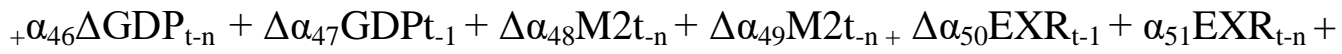
$\Delta \alpha_{52} \mathrm{TAX}_{\mathrm{t}-1}+\Delta \alpha_{53} \mathrm{TAX}_{\mathrm{t}-1}+\Delta \alpha_{54} \mathrm{GEX}_{\mathrm{t}-1}+\Delta \alpha_{55} \mathrm{GEX}_{\mathrm{t}-1}+\Delta \alpha_{56} \mathrm{INF}_{\mathrm{t}-1}+\alpha_{57} \mathrm{INF}_{\mathrm{t}-\mathrm{n}}$

$\Delta \mathrm{GE}_{\mathrm{t}}=\alpha_{50}+\mathrm{GDP}_{\mathrm{t}-1}+\alpha_{51} \mathrm{M}_{2 \mathrm{t}}+\alpha_{52} \mathrm{EXR}_{\mathrm{t}-1}+\alpha_{53} \mathrm{TAX}_{\mathrm{t}-1}+\alpha_{54} \Delta \mathrm{GE}_{\mathrm{t}-1}+\alpha_{55} \Delta \mathrm{INF}_{\mathrm{t}-1}$ ${ }_{+} \alpha_{56} \Delta \mathrm{GDP}_{\mathrm{t}-\mathrm{n}}+\Delta \alpha_{57} \mathrm{GDPt}_{-1}+\Delta \alpha_{58} \mathrm{M}_{2 \mathrm{t}_{-\mathrm{n}}}+\Delta \alpha_{59} \mathrm{M}_{2 \mathrm{t}} \mathrm{t}_{-\mathrm{n}} \Delta \alpha_{60} \mathrm{EXR}_{\mathrm{t}-1}+\alpha_{61} \mathrm{EXR}_{\mathrm{t}-\mathrm{n}}+$

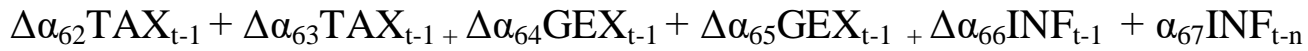

$\Delta \mathrm{INF}_{\mathrm{t}}=\alpha_{60}+\mathrm{GDP}_{\mathrm{t}-1}+\alpha_{61} \mathrm{M}_{2 \mathrm{t}}+\alpha_{62} \mathrm{EXR}_{\mathrm{t}-1}+\alpha_{63} \mathrm{TAX}_{\mathrm{t}-1}+\alpha_{64} \Delta \mathrm{GE}_{\mathrm{t}-1}+\alpha_{65} \Delta \mathrm{INF}_{\mathrm{t}-1}$

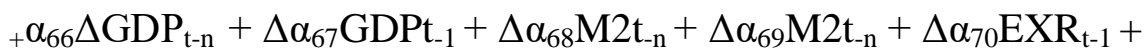

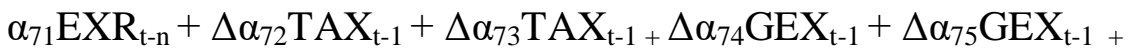
$\Delta \alpha_{76} \mathrm{INF}_{\mathrm{t}-1}+\alpha_{77} \mathrm{INF}_{\mathrm{t}-\mathrm{n}}$ 


\section{RESULTS AND DISCUSSION}

VECM estimation starts from determining the optimum lag in the VECM model. Determining the lag length is very important in estimating the VECM model because the optimal lag is too short; it is feared that it cannot explain the dynamics of the model. However, the lag that VECM uses lag 4 with a $95 \%$ confidence level can be shown in Table 1.

Table 1. VECM estimation results in Indonesia

\begin{tabular}{lcc}
\hline & Estimated results in the long run & \\
\hline GDP $(-1)$ & Coefficient & t-statistics \\
M2 (-1) & 1.000000 & \\
EXR (-1) & -0.033753 & $3.06595^{*}$ \\
GE $(-1)$ & 0.440605 & $4.06598^{*}$ \\
TAX (-1) & 0.178653 & $-5.52591^{*}$ \\
INF $(-1)$ & -0.523258 & $-2.10921^{*}$ \\
C & 0.021864 & $6.01963^{*}$ \\
\hline & -3.909440 & - \\
\hline D(GDP(-1)) & 3.336809 & $2.94321^{*}$ \\
D(M2(-1)) & 0.001223 & 0.23103 \\
D(EXR(-1)) & 3.739753 & $2.83137^{*}$ \\
D(GE(-1)) & -0.111723 & -0.41487 \\
D(TAX(-1)) & -0.204963 & -0.62765 \\
D(INF(-1)) & -0.001597 & -1.05097 \\
\hline
\end{tabular}

* significant $\alpha=5 \%$, with $t$-table $=2.01174$

The estimation results from Table1 for the long-run VECM model for the full period can be interpreted in the equation:

GDP $=-3.909440-0.033753 \mathrm{M}_{\mathrm{t}-1}+0.440605 \mathrm{EXR}_{\mathrm{t}-1}+0.178653 \mathrm{GE} \mathrm{t}-1-0.523258 \mathrm{TAX} \mathrm{t}_{\mathrm{t}}+[$ $\left.6.01846]^{* 4.06598}\right]^{*}[5.52591]^{*} \quad[2.10921]^{*} 0.021864 \mathrm{INF}_{\mathrm{t}-1}+\mathrm{e}_{\mathrm{t}}$

The equation model is significant when the t-statistic value is greater than the $t$ table, namely 2.01174. The long-term estimate in the full period with the research range from 1970 to 2017 on the money supply variable (M2) has a t-statistic value of 3.06595, which is greater than the t-table value, and this means that M2 has a significant positive effect on GDP. The coefficient value of M2 is 0.033753 , meaning that when there is a one percent decrease in M2, it will reduce GDP by 0.03 percent. The exchange rate variable (EXR) has a significant positive effect on GDP. The coefficient value of EXR is 0.440605 , meaning that exchange rate depreciation (EXR) will reduce GDP by 4.40 percent. The government expenditure variable (GE) has a significant negative effect on GDP. The coefficient value of GE is 0.178653 , meaning that every one percent decrease in government spending (GE) will reduce GDP by 1.78 percent. The tax variable (TAX) has a significant negative effect on GDP. The coefficient value of tax (TAX) of 0.523258 means that a one percent reduction in tax (TAX) will reduce GDP by 5.23 percent.

While in the short term, in the estimation results of the VECM model, the independent variable of money (M2) in circulation has a statistical value of 0.23103 and a coefficient value of 0.001223 . It means that the money supply (M2) in the short term does not affect GDP, and every one percent decrease (M2) will reduce GDP by 0.01 percent. The exchange rate variable (EXR) has a statistical value of 2.83137 , greater than the coefficient value of the exchange rate (EXR) of 3.739753. It means that in the 
short term, the exchange rate (EXR) has no significant effect on GDP, and when the exchange rate depreciation (EXR) occurs, it will reduce GDP. by 3.74 percent. The government expenditure variable (GE) has a statistical value of 0.41487 with a coefficient value of 0.111723 , which means that government spending (GE) in the short term has no significant effect on the business cycle (GDP). Every one percent decrease in government spending (GE) will reduce GDP by 1.11 percent. The tax variable has a statistical value of 0.62765 and a coefficient value of 0.204963 , which means that tax (TAX) in the short term does not have a significant effect on the business cycle (GDP). Each one percent reduction in tax (TAX) will reduce GDP by 2.04 percent.

Furthermore, government spending variables have a negative effect on the business cycle in the long run, with a significance level of $1 \%$. This is evident from the statistical value that is higher than the t-table value, namely 5.52591> 2.01174. This means that if there is a change in government spending in the previous year by $1 \%$, it will reduce the business cycle by $0.18 \%$. The same thing happens to the tax variable, where the tax variable has a negative effect on the long-term business cycle with a significance level of $1 \%$. This is evident from the statistical value that is higher than the t-table value, namely $2.10921>2.01174$. When there is a change in the tax in the previous year by $1 \%$, it will reduce the business cycle by $0.5 \%$.

The results of the Impulse Response Function show the magnitude of the response of an endogenous variable due to a shock that occurs in other variables by one standard deviation. IRF can be used to determine how an unexpected change or shock affects other variables. The IRF estimation in this study uses ten periods to describe the response between variables both in the short and long term.

Response to Cholesky One S.D. (d.f. adjusted) Innovations

Response of GDP to GDP

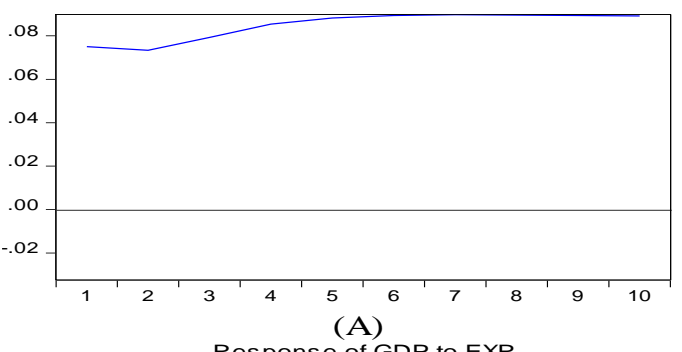

Response of GDP to EXR

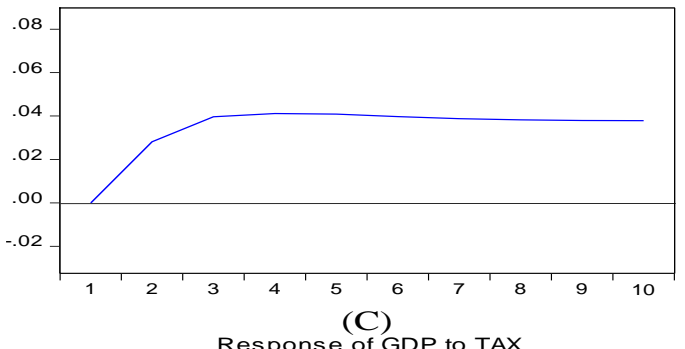

Response of GDP to TAX

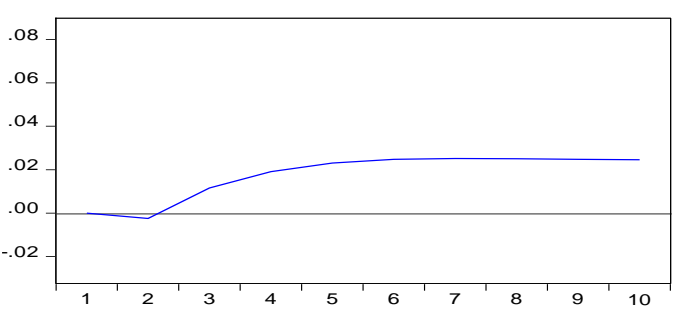

(E)
Response of GDP to M2
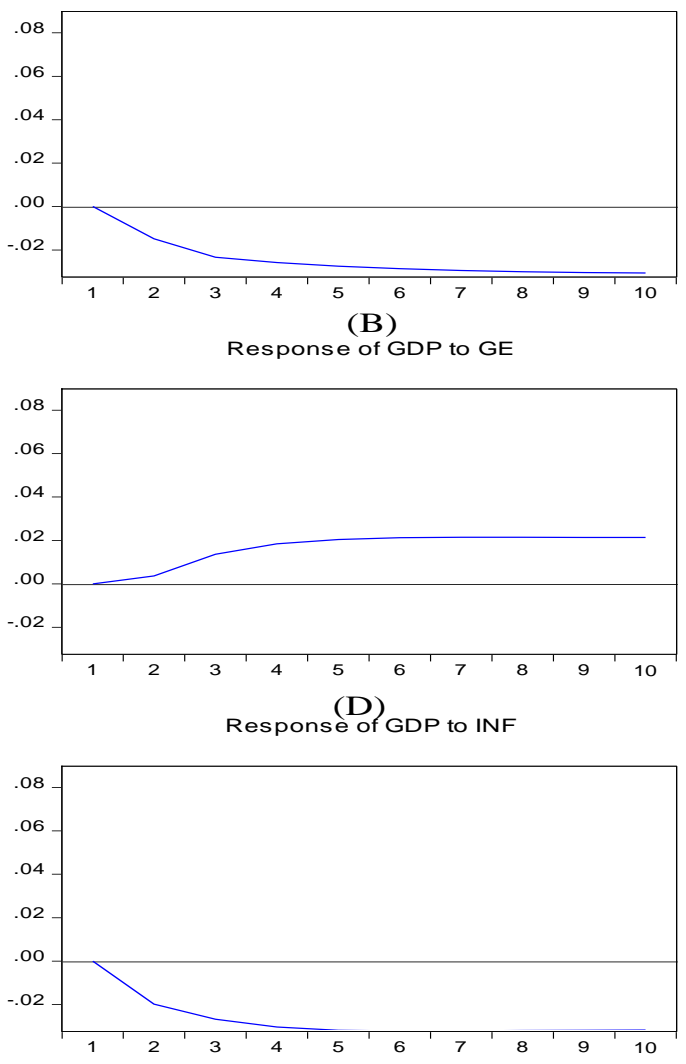

(F)

Figure 2. The Impulse Response Function 
Based on Figure 2, explains the response of the fundamental macroeconomic variables used in this study, namely Gross Domestic Product (GDP / GDP), money supply (M2), an exchange rate (EXR), government spending (GE), taxes (TAX), and inflation (INF). In this study, only the Impulse Response Function results from the GDP response based on the business cycle theory are displayed. So it will be seen how the GDP responds as a proxy for the business cycle due to the shock of monetary policy and fiscal policy. Figure 2 (A) explains the response of the GDP variable to the growth pattern of the business cycle, which is proxied using GDP. It indicates that in the long term, the movement of the GDP response is convergence which illustrates the cointegration of GDP.

Figure 2 (B) illustrates the movement pattern of the GDP response to shocks that occur in the money supply variable. GDP responds negatively from the beginning of the period to the second period by -0.2. It continues in the next period until the 10 th period the money supply shock is responded negatively by GDP. These shocks can occur due to the determination of the money supply by the government. Changes in the money supply will initially increase inflation. Still, they will tend to move stably in the long run, as evidenced by the movement of the inflation response towards the equilibrium point. So this will have an impact on GDP, which responds negatively to the money supply.

GDP response to shocks that occur at exchange rates is shown in Figure 2 (C). The pattern of movement in the GDP response tends to be stable so that during period 1 to period 10, it does not fluctuate too much, and the movement is not far from the equilibrium point. Dominant GDP responds positively to exchange rate shocks. In addition, the stable GDP response shows that changes in the exchange rate do not directly affect GDP but rather conditions of output stability. The next IRF estimation result is the shock that occurs in the government expenditure variable, as shown in Figure 2 (D). At the beginning of the period, the response to government spending is stable, starting at the balance line of 0.25 , and then from the 3rd period to the 10th period, the GDP response to government spending increases. It is due to the policies carried out by the government relating to state spending for infrastructure development and others. So that in the long run, this affects GDP.

Figure 2 (E) shows the movement pattern of the GDP variable response to taxes. GDP responds negatively at the beginning of the period, which is close to the equilibrium point, then in the second period, it has a negative response of 0.15 . However, a positive response began to occur in the 3 rd period until the 10th period, and the movement was quite stable. The government policy issued a tax policy through tax amnesty, which will indirectly respond positively to GDP. The next estimation result is related to the GDP response to inflation. In the picture above, it can be seen that GDP responds negatively to inflation movements. It can be seen in the first period of 0.01 . The next period until the 10th period GDP is more dominant in responding negatively with a relatively large level of fluctuation to inflation shocks. Shocks that occur to inflation reflect fluctuations in national economic growth that domestic and external factors can cause. In general, Indonesia's inflation shocks were more due to global economic fluctuations, mainly stemming from economic shocks and policies of the Indonesian government and developed countries.

The VECM results, when viewed from the level of significance of the effect of the tax variable between the long and short run, are different. It can be seen from the longterm negative coefficient value, but the t-statistic value is significant, influencing 
economic growth. In contrast, in the short term, the coefficient value is negative. Still, the t-statistical value is not significant, meaning that it does not significantly affect economic growth. This difference can be seen from the two sides. First, in the long term, increased economic growth will impact increasing taxes and vice versa, with the increase in economic growth indicating that if the output of society increases, it will impact the community's ability to make taxpayer payments.

Meanwhile, the increased tax revenue indicates an increase in the government's ability to provide public goods to impact the smooth process of economic activity, which will lead to increased economic growth. Tax revenue and economic growth have no relationship between tax revenue and economic growth. It means that tax revenue's value should increase when economic growth increases, which will impact tax revenue. High economic growth indicates that increased social welfare will impact the community's ability to pay taxpayers. If the community is more productive, the tax revenue itself will also increase.

Based on the VECM estimation results that we estimate, there is a unidirectional relationship between fiscal policy, namely government spending and taxes on the business cycle. It is in line with the research of Viphindrartin (2021), Stimson et al. (2013), and Chen et al. (2021). Based on the VECM estimation results that we estimate, there is a unidirectional relationship between fiscal policy, namely government spending and taxes on the business cycle. It explains that fiscal policy is more effective in driving Indonesia's economic (business) cycle. This is in line with the research of Caprio \& Bacchetta,(2012), dan Sequeira (2021).

The fiscal and monetary authorities, namely the government and Bank Indonesia, are expected to improve the domestic economy to compensate for the decline in global demand so that fiscal stimulus can be carried out by increasing government spending and reducing taxes. Other policies can be seen from the monetary easing, which is not limited to interest rates and quantitative easing, for example, buying securities to increase liquidity in the economy. The combination of the direction of changes in monetary policy that tends to be tight with the direction of change from a fiscal perspective that is balanced between tight and loose is thought to have not made an optimal contribution to the welfare of the people in Indonesia. The coordination of monetary and fiscal policies can clearly separate these policies based on the policy grace structure.

Monetary policy is used to stabilize the economy in the short term, while fiscal policy is used to achieve economic targets in the long term. Long-term policies originating from the monetary authority can be focused on maintaining stable price stability. The interaction of monetary and fiscal policies aims to reconcile the differences in assumptions or perceptions between the two authorities regarding the right policies.

A well-executed connection between monetary policy and fiscal policy effectively realizes economic growth and inflation stability in the long and short term. Monetary policy by increasing the money supply or applying an exchange rate system will impact economic growth and inflation rates over a long time and fiscal policy by increasing government spending and taxes. Meanwhile, when crowding out occurs, the impact of autonomous spending (fiscal policy) decreases because it causes the interest rate to rise, so that private investment spending decreases.

When the economy is in full employment, an increase in spending (aggregate spending) will not increase output because all production factors are fully operational. 
An increase in government spending, for example, will only push up prices. In the short term, it may increase income, but an increase in income will increase the demand for money. In contrast, the money supply is tight, what happens is an increase in the interest rate, and in turn, it will reduce aggregate expenditure so that income and output fall back down. It means that government spending has replaced investment spending (crowding out).

When the economy is full employment, fiscal expansion (increasing government spending) does not increase income but instead encourages an increase in the government budget deficit (a budget deficit) because the government has to borrow from the public to finance this deficit. Because income does not increase, saving also does not increase; as a result, public funds available for private investment are reduced so that investment decreases, meaning that there is a crowding out. However, if the increase in government spending causes income to rise so that public saving also increases, the funds available for private investment will increase so that the crowding out will not occur in full.

Fiscal expansion in a full-employment economy causes the interest rate to rise. At the same time, income and output do not increase, which can be prevented if this fiscal expansion is accompanied by monetary expansion. An increase in the money supply lowers the interest rate so that crowding out does not occur. The result is that output and income increase, but the interest rate remains relatively constant. This policy is called the accommodating policy.

The application in the short term sees a small percentage of its effect on economic growth and inflation, so other policies that are more responsive and effective are needed to encourage the rate of economic growth and inflation stability. However, based on this research, expansionary monetary policy by increasing the money supply and expansionary fiscal policy with government spending and taxes are more effective in influencing economic growth and inflation in the short term.

\section{CONCLUSIONS AND RECOMMENDATIONS}

\section{Conclusions}

The money supply variable with the symbol (M2) and the business cycle variable has a significant relationship that affects each other in the long run. In contrast, the VECM estimate in the short term, the money supply does not significantly affect the business cycle. It indicates that the money channel as one of the channels in the monetary transmission mechanism is ineffective in the short term to realize business cycle growth in Indonesia.

The exchange rate variable with the symbol (EXR) as a proxy for monetary policy variables other than the money supply has a significant positive effect on the business cycle in both the long and short term.

There is a unidirectional relationship between fiscal policy, namely government spending and taxes on the business cycle. It explains that fiscal policy is more effective in driving Indonesia's economic (business) cycle. Meanwhile, the estimation results of VECM estimation in the long term from the two fiscal variables, namely government expenditure and taxes, have a negative effect on the business cycle in Indonesia. Meanwhile, the VECM estimation in the short term government expenditure and taxes do not significantly influence the business cycle. 


\section{Recommendations}

The suggestions outlined in this study aim to increase the effectiveness of monetary and fiscal policies in maintaining price and output stability. A well-executed connection between monetary policy and fiscal policy effectively realizes economic growth and inflation stability in the long and short term. Monetary policy by increasing the money supply or applying an exchange rate system will impact economic growth and inflation rates over a long time and fiscal policy by increasing government spending and taxes. Meanwhile, when crowding out occurs, the impact of autonomous spending (fiscal policy) decreases because it causes the interest rate to rise, so that private investment spending decreases. So there are several ways to overcome the crowding-out problem. When the economy is in full employment, the increase in spending (aggregate spending) will not increase output because all production factors are already working full time. An increase in government spending, for example, will only push up prices. In the short term, it may increase income, but an increase in income will increase the demand for money. In contrast, the money supply is tight, what happens is an increase in the interest rate, and in turn, it will reduce aggregate expenditure so that income and output fall back down. It means that government spending has replaced investment spending (crowding out).

When the economy is full employment, fiscal expansion (increasing government spending) does not increase income but encourages an increase in the government budget deficit (a budget deficit) because the government has to borrow from the public to finance this deficit. Because income does not increase, saving also does not increase. As a result, public funds available for private investment are reduced to decrease investment, meaning a crowding out. However, if the increase in government spending causes income to rise so that public saving also increases, the funds available for private investment will increase so that the crowding out will not occur fully. Fiscal expansion in a full-employment economy causes the interest rate to rise. At the same time, income and output do not increase, which can be prevented if this fiscal expansion is accompanied by monetary expansion. An increase in the money supply lowers the interest rate so that crowding out does not occur. The result is that output and income increase, but the interest rate remains relatively constant. This policy is known as the accommodating policy. The application in the short term sees a small percentage of its effect on economic growth and inflation, so other policies that are more responsive and effective are needed to encourage the rate of economic growth and inflation stability. However, based on this research, expansionary monetary policy by increasing the money supply and expansionary fiscal policy with government spending and taxes are more effective in influencing economic growth and inflation in the short term.

\section{REFERENCES}

Aßhoff, S., Belke, A., Osowski, T. (2021). Unconventional monetary policy and inflation expectations in the Euro area. Economic Modelling, 102 (1), 55-64

Bawono, S., Zainuri., R \& Niken. (2019). Dynamics Of Real Exchange Rate And Three Financial Crisis: Purchasing Power Parity Relative Approach In Indonesia And Thailand. International Journal of Scientific \& Technology Research, 8(5), 58-62

Bogoviz, A. (2020). Complex Systems: Innovation and Sustainability in the Digital Age. Switzerland: Springer

Boakye, E., Zhao, H., Ahia, B. \& Damoah, M. (2020). Mitigating the Socio-Economic Impacts of COVID-19; Role of Governments in Sub-Saharan Africa, Fiscal and 
Monetary Policy Perspectives. Open Journal of Social Sciences, 8, 300-318

Caprio, G., Bacchetta, P. (2012). Handbook of Safeguarding Global Financial Stability. London: Elsevier

Chen, X., Wohlfarth, P., \& Smith, R.P. (2021). China's money demand in a cointegrating vector error correction model. Journal of Asian Economics, 75(1), 13-38.

Clarke, T., O'Brien, J., \& O'Kelley, C. (2019). The Oxford Handbook of the Corporation. Oxford, UK: Oxford University Press

Damayanti, L., \& Rusminingsih, D. (2021). Human Identity Factors in Human Capital Investment in Driving Financial Performance, Case Study of the Islamic Hospitality Industry in Indonesia. Tamansiswa Management Journal International. 1(1), 3-5.

Davar, E. (2016). The 21st Century Scandal Must Be Prevented: Keynes vs Hazlitt. Modern Economy, 7, 353-370.

Dunning, J.H. (2014). Economic Analysis and Multinational Enterprise. London,UK: Routledge

Drean, B. (2021). Education, Microfinance, and Poverty in Philippines. Tamansiswa Accounting Journal International. 1(1), 33-38.

Garang, A., Yacouba, K. \& Thiery, K. (2018). Time Series Bounds Approach to Foreign Direct Investment, Unemployment and Economic Growth in Uganda. Modern Economy, 9, 87-96.

Gerdesmeier, D. (2011). Price Stability: Why is it Important for You?. Frankfurt, Germany: European Central Bank

Gitman, L.J., Joehnk, M.D., Smart,S., \& Juchau, R.H. (2015). Fundamentals of Investing. Frenchs Forest, Australia: Pearson

Grauwe, P.D. \& Ji,Y. (2019). Behavioural Macroeconomics: Theory and Policy. Oxford, UK : Oxford University Press

Handa, J. (2008). Monetary Economics. London: Routledge

Harnphattananusorn, S. \& Puttitanun, T. (2021). Generation gap and its impact on economic growth. Heliyon, 7(6), 7-16.

Hartley, J., Hoover,K. \& Salyer, K.D. (2013). Real Business Cycles: A Reader. London,UK: Routledge

Herzog, B. (2014). Applied Mathematical Theory for Monetary-Fiscal Interaction in a Supranational Monetary Union. Journal of Applied Mathematics and Physics, 2, 737-744

Hidayanti, F.A. \& Prabowo, B.H. (2021). Monetary Analysis of Indonesia's Economic Growth After the Asian Financial Crisis. Tamansiswa Accounting Journal International. 1(1),3-5.

Hutton, W. (2012). The Revolution That Never Was. London: Penguin

Jacobs, J. (2012). Econometric Business Cycle Research. Cham, Switzerland: Springer

Mao,X., Yang, A.C., Peng, C.K., \& Shang,P. (2020). Analysis of economic growth fluctuations based on EEMD and causal decomposition. Physica A: Statistical Mechanics and its Applications, 553(1), 46-61.

Marglin, S.A. (2018). Raising Keynes: A General Theory for the 21st century. EconomiA, 19(1), 1-11.

McDonald, J. \& Stokes, H. (2015). Monetary Policy, Fiscal Policy, and the Housing Bubble. Modern Economy, 6, 165-178.

Melicher, R.W., \& Norton, E.A. (2013). Introduction to Finance: Markets, 
Investments, and Financial Management. Hoboken, USA: John Wiley and Sons Omofa, M. (2017). An Assessment of the Effect of Financial Sector Development on Growth and Unemployment in Nigeria: 1986-2012. Open Journal of Business and Management, 5, 34-50.

Sequeira, J.M. (2021). Monetary policy surprises, stock returns, and financial and liquidity constraints, in an exchange rate monetary policy system. The Quarterly Review of Economics and Finance, 81(1), 226-236.

Song, M., Ma, X., Shang,Y., Zhao, X. (2020). Influences of land resource assets on economic growth and fluctuation in China. Resources Policy, 68(1) , 70-79.

Stimson, R.J., Stough, R.R., \& Roberts, B.H. (2013). Regional Economic Development: Analysis and Planning Strategy. Cham,Switzerland: Springer

Viphindrartin, S. (2021). Impact of Macro Economy on Financial Stability in Malaysia. Tamansiswa Management Journal International. 1(1). 34-38.

Villanthenkodath, M.A. \& Mahalik, M.K. (2021). Does economic growth respond to electricity consumption asymmetrically in Bangladesh? The implication for environmental sustainability. Energy, 233(1), 21-42.

Vroey, M.D. (2016). A History of Macroeconomics from Keynes to Lucas and Beyond. New York, USA: Cambridge University Press

Widarni, E.L. \& Bawono, S. (2021). Human Capital, Technology, and Economic Growth: A Case Study of Indonesia. The Journal of Asian Finance, Economics and Business. 8 (5). 29-35.

$\mathrm{Xu}, \mathrm{Q}$. (2020). Macro Monetary Policy and Micro Corporate Behavior. Modern Economy, 11, 740-749. 